\title{
Use of ELISA based on NcSRS2 of Neospora caninum expressed in Pichia pastoris for diagnosing neosporosis in sheep and dogs
}

Utilização de um ELISA baseado em NcSRS2 de Neospora caninum expressa em Pichia pastoris para diagnóstico de neosporose em ovinos e cães

Amanda Fernandes Pinheiro ${ }^{1}$; Sibele Borsuk²; Maria Elisabeth Aires Berne ${ }^{1}$; Luciano da Silva Pinto²; Renato Andreotti ${ }^{3}$; Talita Roos ${ }^{1}$; Barbara Couto Roloff'; Fábio Pereira Leivas Leite ${ }^{1,2 *}$

\begin{abstract}
${ }^{1}$ Departamento de Microbiologia e Parasitologia, Instituto de Biologia, Universidade Federal de Pelotas - UFPel, Pelotas, RS, Brazil ${ }^{2}$ Núcleo de Tecnologia, Centro de Desenvolvimento Tecnológico, Universidade Federal de Pelotas - UFPel, Pelotas, RS, Brazil ${ }^{3}$ Centro Nacional Gado de Corte, Empresa Brasileira de Pesquisa Agropecuária - Embrapa, Campo Grande, MS, Brazil
\end{abstract}

Received December 18, 2014

Accepted February 11, 2015

\begin{abstract}
Neosporosis is a disease caused by the protozoon Neospora caninum that leads to significant economic losses in many countries. In the present study, we report on use of the recombinant protein NcSRS2 of $N$. caninum expressed in Pichia pastoris in an indirect immunoenzymatic assay (ELISA) for diagnosing neosporosis infection in sheep and dogs. We observed that the ELISA test yielded specificity of $94.5 \%$ and sensitivity of $100 \%$ for sheep and specificity of $93.3 \%$ and sensitivity of $100 \%$ for dogs. We observed that the sensitivity was higher than shown by the indirect fluorescent antibody test, and this was confirmed by means of Western blot. The results from this study suggest that the recombinant protein expressed in $P$. pastoris is a suitable antigen for use in immunodiagnosis to detect $N$. caninum in two important species exposed to this parasitosis.
\end{abstract}

Keywords: Neospora caninum, Pichia pastoris, NcSRS2, ELISA.

\section{Resumo}

A neosporose é uma doença causada pelo protozoário Neospora caninum que leva a perdas econômicas importantes em muitos países. No presente estudo, é descrita a utilização da proteína recombinante $\mathrm{NcSRS}_{2}$ de $N$. caninum expressa em Pichia pastoris em um ensaio imunoenzimático indireto (ELISA) para o diagnóstico de infecção por Neospora em ovelhas e cães. Observou-se, que utilizando-se um ELISA, o teste produziu uma especificidade de 94,5\% e uma sensibilidade de $100 \%$ para ovinos; e uma especificidade de $93,3 \%$ e sensibilidade de $100 \%$ para cães. Uma maior sensibilidade foi observada em relação à IFI que foi confirmada por Western blot. Os resultados deste estudo sugerem que a proteína recombinante expressa em $P$. pastoris é bom antígeno para ser utilizado no diagnóstico imunológico para detectar $N$. caninum em duas espécies importantes expostas a esta parasitose

Palavras-chave: Neospora caninum, Pichia pastoris, NcSRS2, ELISA.

\section{Introduction}

Dogs are essential to the life cycle of Neospora caninum (DUBEY et al., 2007). They are both the definitive and the intermediate host, and are also epidemiologically important for horizontal transmission to other food animals (GONDIM et al., 1999). Problems due to naturally acquired Neospora infections have also been reported in other food species, including sheep

*Corresponding author: Fábio Pereira Leivas Leite. Núcleo de Biotecnologia, Centro de Desenvolvimento Tecnológico, Universidade Federal de Pelotas, Rua Gomes Carneiro, n. 1, Centro, CP 354, CEP 96010-610, Pelotas, RS, Brasil. e-mail: fabio_leite@ufpel.edu.br
(DUBEY \& LINDSAY, 1990), cattle and goats (DUBEY et al., 1992, 1996).

Several studies have been conducted to identify and characterize the molecular antigenic components of $N$. caninum, in order to improve the performance of serological diagnostic tests and to reveal the mechanisms of its host interactions (HEMPHILL et al., 1999). Information on the antigenicity of Apicomplexa-specific antigens, including in relation to Neospora, is needed in order to avoid cross-reactions with parasites from the same phylum (DUBEY et al., 2003). Serological tests that use this category of 
antigens increase test specificity by reducing possible antibody cross-reactions with common antigens.

NcSRS2 is an immunodominant surface protein that is present in the bradyzoites and tachyzoites of $N$. caninum (FUCHS et al., 1998) and enables specific serological diagnosing of neosporosis. This protein has been expressed on different platforms, including baculovirus systems (NISHIKAWA et al., 2001, 2002) and Escherichia coli (BORSUK et al., 2011; GATURAGA et al., 2005; LIU et al., 2007).

The approach of the present study was to use the yeast species Pichia pastoris as the expression system for producing the protein NcSRS2. This yeast is genetically stable once transformed, and grows in relatively simple culture media, thus making industrial production scale-up of recombinant proteins straightforward (CEREGHINO et al., 2002). Recently, NcSRS2 was expressed in $P$. pastoris by our group and was evaluated in an indirect ELISA test for diagnosing Neospora infection in cattle (PINHEIRO et al., 2013).

In the present study, we were able to demonstrate that ELISA using the recombinant protein NcSRS2 of $N$. caninum expressed in $P$. pastoris showed high specificity and sensitivity when used for diagnosing Neospora infection in sheep and dogs.

\section{Materials and Methods}

\section{Parasites}

The $N$. caninum isolate nc-1 (DUBEY et al., 1988) was used to prepare the antigen for this study. The parasite was propagated in vero cells using Dulbecco's Modified Essential Medium (DMEM), supplemented with $10 \%$ fetal calf serum (FCS) at $37{ }^{\circ} \mathrm{C}$ in a humidified atmosphere of $5 \% \mathrm{co}_{2}$. When $80 \%$ of the vero cells had been destroyed by $N$. caninum tachyzoites, the monolayer was removed and washed twice with phosphate-buffered saline (PBS) solution, with centrifugation at $1000 \mathrm{x} g$ for $10 \mathrm{~min}$.

\section{Serum samples}

The ovine and canine serum samples used in this experiment were collected from endemic areas of neosporosis in the state of Rio Grande do Sul, Brazil. Peripheral blood was collected from the jugular veins of 110 adult sheep using $19 \mathrm{~g}$ needles, and from 65 adult dogs using a $22 \mathrm{~g}$ needle, all attached to Vacutainer tubes (Becton-Dickinson, Rutherford, NJ, USA). The blood was then kept at room temperature for clot formation; centrifuged at $2000 \mathrm{x}$ $g$ for serum separation, for $10 \mathrm{~min}$; and stored at $-20^{\circ} \mathrm{C}$ until used.

\section{Indirect Fluorescent Antibody Test (IFAT)}

Cells infected with $N$. caninum tachyzoites were used to prepare the slide well for IFAT. The serum samples were analyzed at a dilution of 1:50, which was defined as the cutoff point using a previously described method (PARÉ et al., 1995).

The serum samples from each species were diluted and incubated at $37^{\circ} \mathrm{C}$ for $45 \mathrm{~min}$. Secondary fluorescein isothiocyanate-conjugated
IgG (Sigma Chemicals, USA) was then added to the respective species and was incubated at a dilution of 1:1250 in PBS buffer at $37^{\circ} \mathrm{C}$ for $45 \mathrm{~min}$. Each glass slide included negative and positive control serum samples.

\section{Recombinant NcSRS2}

The protein NcSRS2 was expressed as described by Pinheiro et al. (2013). Briefly, the recombinant $P$. pastoris containing the $\mathrm{pPICZ} \alpha \mathrm{B} / \mathrm{NcSRS} 2$ was cultured in a three-liter baffled fermenter containing one liter of BMMY broth at $28^{\circ} \mathrm{C}$, for approximately $48 \mathrm{~h}\left(\mathrm{OD}_{600}=2\right.$ to 6$)$. Expression was induced by means of addition of methanol at $1 \%$ of final concentration for $144 \mathrm{~h}$. The NcSRS2 recombinant protein that was secreted was concentrated and purified by means of precipitation using a $20 \%$ saturated ammonium sulphate solution that was added to the culture supernatant at $4{ }^{\circ} \mathrm{C}$ to make a final concentration of $50 \%$. The precipitated proteins were collected by means of centrifugation at $10,000 \times g$ at $4{ }^{\circ} \mathrm{C}$ for $15 \mathrm{~min}$, suspended in PBS buffer and then dialyzed in deionized water for $72 \mathrm{~h}$.

\section{Western blot}

Purified recombinant NcSRS2 and an unrelated recombinant protein (negative control) were used for Western blot analysis on positive and negative ovine and canine serum samples. The samples were mixed with SDS gel-loading buffer (100 mM Tris$\mathrm{HCl}$ at $\mathrm{pH}$ 6.8, $100 \mathrm{mM}$ 2-mercaptoethanol, 4\% SDS, 0.2\% bromophenol blue and $20 \%$ glycerol), under reducing conditions. The samples were brought to $100{ }^{\circ} \mathrm{C}$ for $10 \mathrm{~min}$ and subjected to SDS-PAGE, after which the proteins in the gel were electrically transferred to nitrocellulose membranes (GE Healthcare, UK). The membranes were blocked with PBS containing 5\% skimmed milk (PBS-SM) for $1 \mathrm{~h}$ at room temperature and were incubated with sheep serum (1:100 with PBS-SM) and dog serum (1:50 with PBS-SM) at room temperature for $1 \mathrm{~h}$. They were then washed with PBS at pH 7.6 containing 0.5\% Tween 20 (PBS-T), three times for $5 \mathrm{~min}$ each. Following this, they were incubated with anti-sheep or anti-canine secondary peroxidase-conjugated IgG (Sigma Chemicals, USA), respectively, diluted to 1:4000 with PBS-SM at room temperature for $1 \mathrm{~h}$. The reacting bands were revealed using 3,3'-tetrahydrochloride $(\mathrm{DAB})$ and $\mathrm{H}_{2} \mathrm{O}_{2}$.

\section{Indirect enzyme-linked immunosorbent assays (ELISA)}

Polystyrene 96-well microtiter plates (Polysorp Nunc, USA) were coated overnight at $4{ }^{\circ} \mathrm{C}$ with $50 \mathrm{ng} /$ well of recombinant protein NcSRS2 in $0.05 \mathrm{M}$ carbonate-bicarbonate buffer ( $\mathrm{pH}$ 9.6). The plates were then washed three times using 0.01 M PBS with $0.05 \%$ Tween 20 (PBS-T) and blocked using 0.01 M PBS with $5 \%$ nonfat milk at $37{ }^{\circ} \mathrm{C}$ for $1 \mathrm{~h}$. After three washes with PBS-T, the positive and negative control sera and serum samples were diluted at 1:100 in 0.01 M PBS-T and added in duplicate to the plate, and were then incubated at $37^{\circ} \mathrm{C}$ for $1 \mathrm{~h}$. After three washes, $100 \mu \mathrm{L} /$ well of ovine or canine secondary peroxidase-conjugated IgG (Sigma Chemicals, USA) was added, diluted at 1:4000 in $0.01 \mathrm{M}$ 
PBS-T, followed by incubation at $37^{\circ} \mathrm{C}$ for $1 \mathrm{~h}$. After another five washes, $100 \mu \mathrm{L}$ of substrate ( $o$-phenylenediamine dihydrochloride; OPD tablets, Sigma Chemicals, USA) in phosphate-citrate buffer $(0.4 \mathrm{mg} / \mathrm{mL})$ containing $0.04 \%$ of $30 \%(\mathrm{v} / \mathrm{v})$ hydrogen peroxide, at $\mathrm{pH} 4.0$, was added to each well, and the plates were incubated in the dark at room temperature for $15 \mathrm{~min}$. Following incubation, $50 \mu \mathrm{L}$ of stop buffer $\left(1 \mathrm{~N} \mathrm{H}_{2} \mathrm{SO}_{4}\right)$ was added.

The mean optical density (OD) at $492 \mathrm{~nm}$ was determined for all test wells using a microtiter plate reader (Multiskan MCC/340 MKII, Alabama, USA). The same positive and negative control sera were used for interplate control.

\section{Statistical analysis}

To accurately assess the assay for diagnostic specificity, sensitivity, cutoff and predictive value, the results from the 110 ovine and 65 canine serum-confirmed positive and negative samples were subjected to receiver operating characteristic (ROC) analysis using the MedCalc statistical software (version 10.3.0.0, www. medcalc.be).

\section{Results}

\section{Recombinant NcSRS2}

In order to confirm that the transformed $P$. pastoris was expressing the recombinant protein, cultures were induced with methanol and the expression was confirmed by means of dot blotting using anti 6xhisTag monoclonal antibodies (data not shown). The concentrated and purified protein was then confirmed according to molecular weight, with SDS-PAGE and Western blot. We were also able to confirm protein expression by probing with serum from naturally infected animals (Figure 1a). These results suggested that the recombinant protein presented conformation similar to the protein of the protozoa in their native form.

\section{IFAT and ELISA-NcSRS2}

An ELISA test using the NcSRS2 protein (ELISA-NcSRS2) was standardized. From the sheep, 110 serum samples were used, comprising 37 positive and 73 negative samples. From the dogs, a total of 21 positive and 44 negative serum samples were used. In order to determine the best serum dilution to use in the assay, a check board was undertaken using different antigen concentrations and serum dilutions. A dilution that fell within the linear range of the ELISA results was used. The correlation between the two diagnostic tools was assessed using ROC analysis.

Among the 73 IFAT-negative sheep serum samples, two were found to be above the cutoff point. In the canine population analysis, considering a cutoff value of 0.21 for 15 IFAT-negative canine serum samples, only four samples were above the cutoff point. To examine whether these results were due to the specificity of the test or due to the statistical analysis conducted, a Western blot test was performed on these samples (Figure 1c). We observed that four canine samples that were negative for IFAT showed a
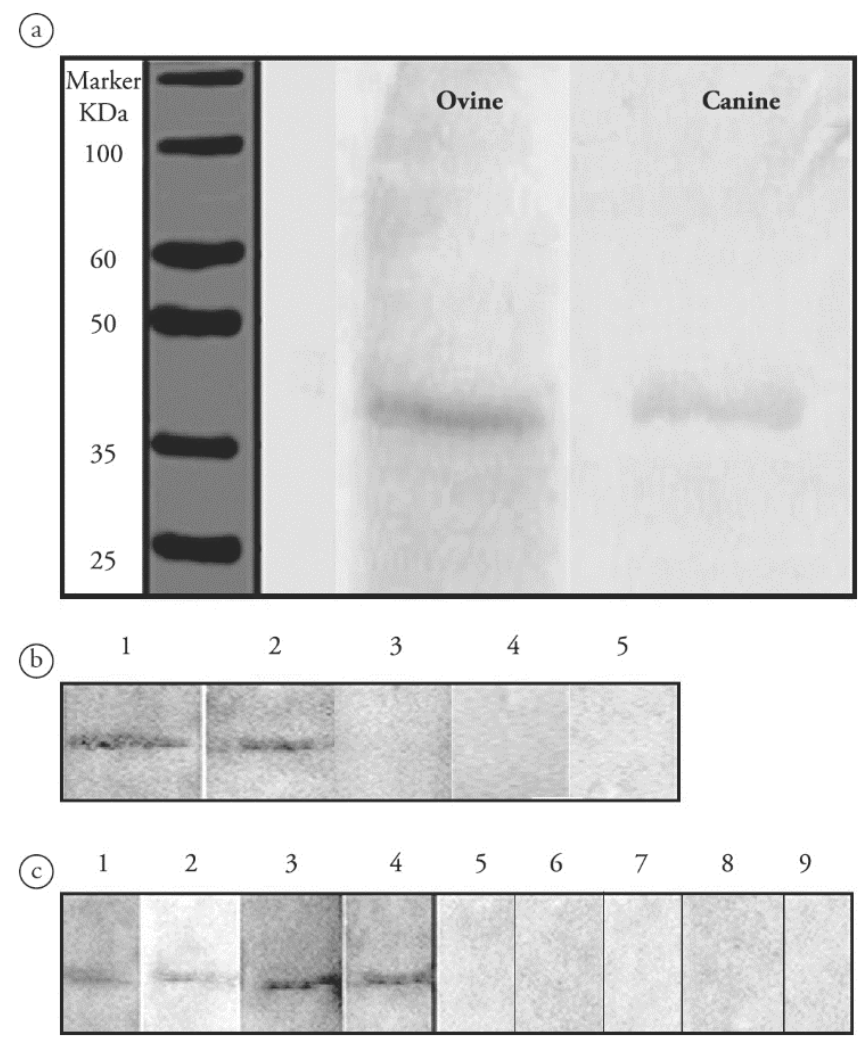

Figure 1. (a) Western Blot using recombinant NcSRS2 protein expressed in the $P$. pastoris system. The recombinant protein reacted with serum samples from animals (sheep and dogs) naturally infected with $N$. caninum. Full-range rainbow molecular weight marker (GE). (b) Samples 1 and 2 are from sheep serum that was IFAT-negative, but reacted above the ELISA threshold (i.e. they were positive), and samples 3, 4 and 5 were IFAT-positive and reacted under the ELISA threshold (i.e. they were negative). (c) Samples 1 to 4 are from dogs that were IFAT-negative, but reacted above the ELISA threshold (i.e. they were positive), and samples 5 to 9 were IFAT-positive and reacted under the ELISA threshold (i.e. they were negative).

band in the Western blot test, and thus these animals above the cutoff were confirmed as positive although detected by means of IFAT. The same occurred with two ovine serum samples (Figure 1b) in which the band was present in the Western blot test, thus suggesting that the specificity of the ELISA test was higher than that of the IFAT.

\section{Sensitivity, specificity and predictive values}

Figures 2 and 3 show the frequency distribution of the IFATpositive and negative ovine and canine serum samples. Among the sheep, with a mean ELISA OD of 0.25 as the threshold value, the results yielded specificity of $94.5 \%$ and sensitivity of $100 \%$. Using these same values as a cutoff point $(\mathrm{OD} \leq 0.25)$, the negative predictive value of the test was $100 \%$ and the positive predictive value ranged from 69.8 to $99.4 \%$, for neosporosis prevalence of 10 to $90 \%$ (Figure 2c). In the canine population using the same ROC analysis, and considering serum samples with a mean ELISA 
(a)

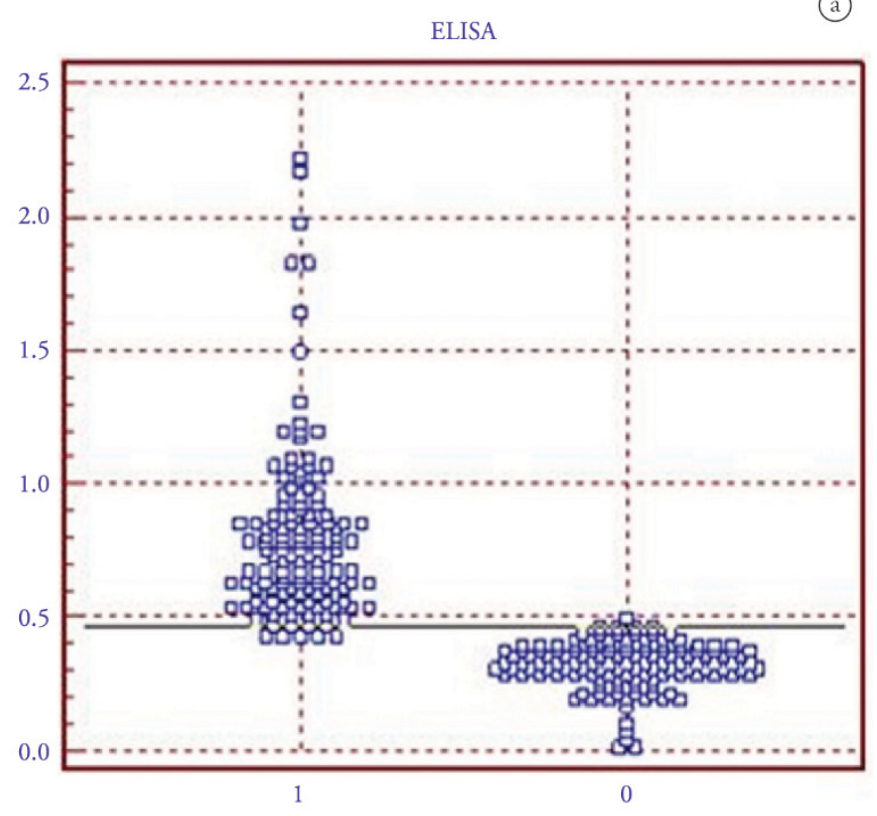

IFI

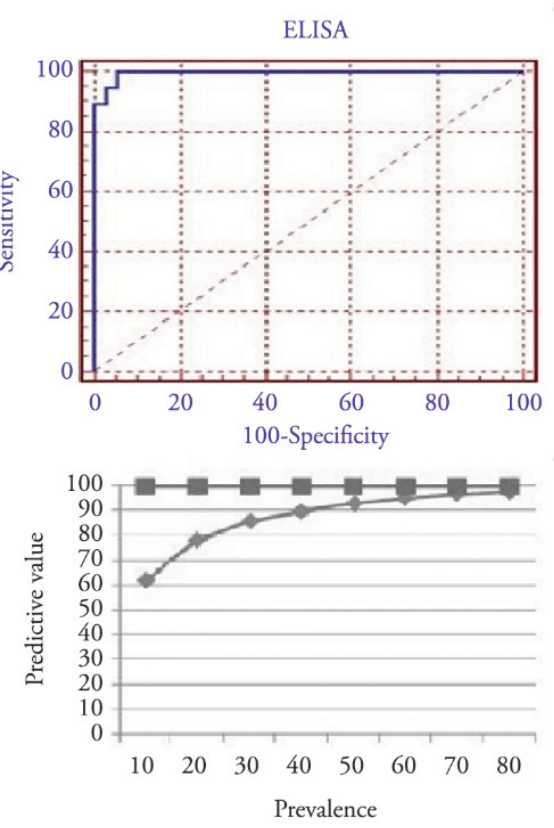

(b)

Figure 2. ROC analysis on the ELISA-NcSRS2 test using 37 confirmed positive and 73 confirmed negative sheep serum samples (as shown using the indirect fluorescence antibody test). (a) Frequency distribution of the confirmed positive (1) and confirmed negative (0) serum samples. The samples were considered positive when the cutoff values were greater than or equal to a mean ELISA absorbance value of 0.25 . (b) ROC plot. Area under curve $=0.996$ (0.008); $95 \%$ confidence interval from 0.958 to 0.997 . (c) Negative predictive values (squares) and positive predictive values (diamonds) associated with the ELISA-NcSRS2 test for varying prevalence levels of neosporosis, determined using ROC analysis based on mean OD threshold values in ELISA.

(a)

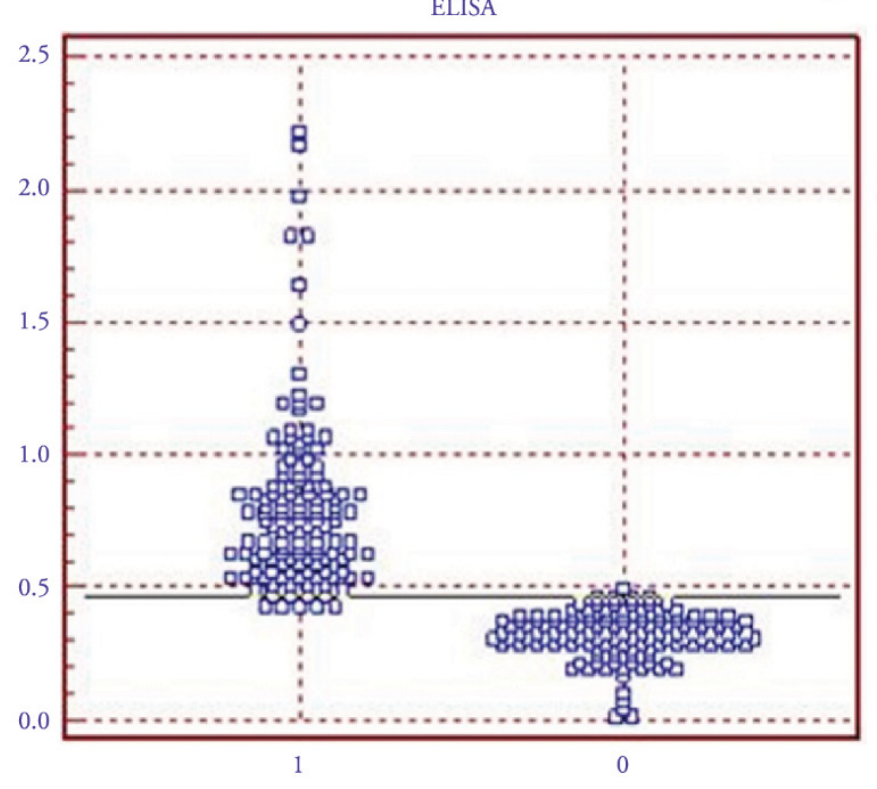

IFI
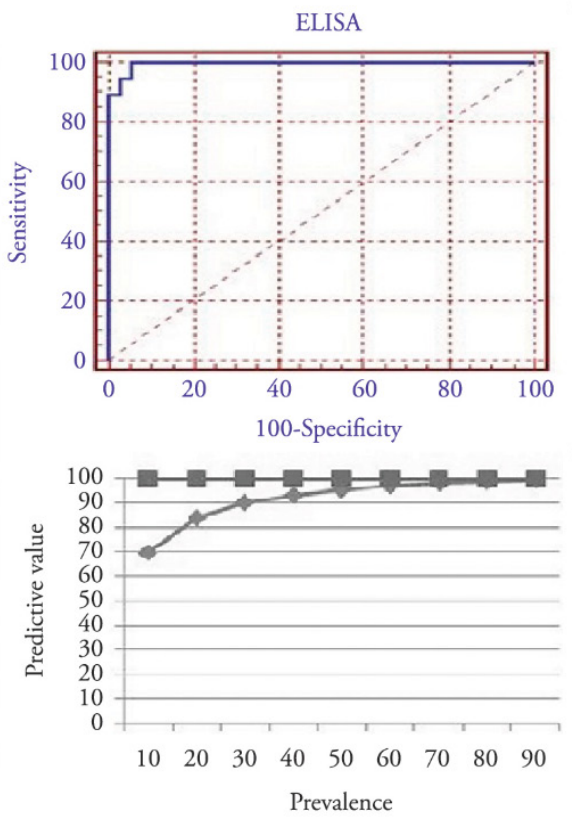

(b)

(c)

Figure 3. ROC analysis on the ELISA-NcSRS2 test using 21 confirmed positive and 44 confirmed negative canine serum samples (as shown using the indirect fluorescence antibody test). (a) Frequency distribution of the confirmed positive (1) and confirmed negative (0) serum samples. The samples were considered positive when the cutoff values were greater than or equal to a mean ELISA absorbance value of 0.21 . (b) ROC plot. Area under curve $=0.986$ (0.018); $95 \%$ confidence interval from 0.919 to 0.997 . (c) Negative predictive values (squares) and positive predictive values (diamonds) associated with the ELISA-NcSRS2 test for varying prevalence levels of neosporosis, determined using ROC analysis based on mean OD threshold values in ELISA. 
OD cutoff value of 0.21 , the test yielded specificity of $93.3 \%$ and sensitivity of $100 \%$. Using the same cutoff value, the negative predictive value of the test was $100 \%$ and the positive predictive value ranged from 69.8 to $99.4 \%$, for neosporosis prevalence of 10 to $90 \%$ in a specific area (Figure 3c).

\section{Discussion}

Sheep herds and dog populations are epidemiologically important in relation to transmission of parasitoses and are susceptible to neosporosis. Therefore, standardization of the diagnostic assays for detecting $N$. caninum infection within these populations is of great importance. Many serological tests for detecting N. caninum antibodies have been described (DUBEY \& SCHARES, 2006), including IFAT and ELISA based on either whole or partially purified native $N$. caninum antigens (GHALMI et al., 2009). However, there is still a need for $N$. caninum-specific serological assays, to allow for further identification of definitive and/ or intermediate hosts, so as to make accurate herd diagnoses and conduct epidemiological investigations on risk factors and transmission.

To achieve higher sensitivity, commercial ELISA and IFAT kits use whole tachyzoites as antigens for $N$. caninum. However, this can lead to decreased specificity, which in turn, leads to falsepositive results due to cross-reactions with other related species (AHN et al., 2003). Even though different serological methods exist, IFAT is still the test predominantly used. On the other hand, IFAT is complex and subjective, which may compromise its effectiveness in large-scale epidemiological investigations. A low-cost test for the livestock industry, such as ELISA, with the capacity to detect specific Neospora antibodies, would make an important contribution towards controlling this disease.

Use of a single antigen has the potential to increase the diagnostic specificity, as is the case of the NcSRS2 antigen of $N$. caninum. It is conserved in different isolates and is the immunodominant antigen recognized by serum from naturally infected animals (HOWE et al., 1998). In previous studies, recombinant NcSRS2 protein was used to develop ELISA tests for diagnosing of $N$. caninum infection and, in most of them, the protein was expressed through a prokaryotic system (GATURAGA et al., 2005; LIU et al., 2007; BORSUK et al., 2011; SA et al., 2014) or using a baculovirus approach (NISHIKAWA et al., 2001).

Recently, we reported on the expression of recombinant NcSRS2 from $N$. caninum, expressed in P. pastoris (PINHEIRO et al., 2013). In this study, we were able to demonstrate by means of Western blot and ELISA that the recombinant protein was recognized by antibodies from sheep and dogs naturally infected with $N$. caninum, thus suggesting that epitopes of the native protein were conserved in the recombinant protein (PINHEIRO et al., 2013). Furthermore, we observed that this protein did not react with serum from animals that were naturally infected with parasites from the same order and family (Toxoplasma gondii), thus demonstrating that serum from two different species naturally infected with $N$. caninum reacted positively to this protein.

The data obtained in the present study, using ELISA with recombinant NcSRS2 expressed in P. pastoris as the antigen, suggest that this is a promising system with regard to the possibility of expansion to industrial-scale protein production. The sensitivity and specificity results obtained demonstrated great potential, with $100 \%$ and $94.5 \%$ for sheep and $100 \%$ and $93.3 \%$ for dogs, respectively.

In Brazil, only a few studies on the prevalence of neosporosis in sheep herds have been conducted. The prevalence in the state of Paraná has been reported to be 9.5\% (ROMANELLI et al., 2007) and the rate in the state of Rio Grande do Norte has been described as ranging from 1.8\% (SOARES et al., 2009) to $8.1 \%$ (UENO et al., 2009). If the prevalence in sheep herds is taken to be $10 \%$, the ELISA test with an OD cutoff point of 0.25 described in this study would give rise to positive prediction values of around $70 \%$ and negative prediction values of $100 \%$.

Dogs are epidemiologically important in relation to horizontal transmission of this protozoon to other animals (DUBEY et al., 2007). There is evidence of a relationship between $N$. caninum infection in dogs and cattle (WOUDA et al., 2000; WOUDA et al., 1999), as well as an increased risk of neosporosis among sheep and goat herds when they are exposed to contact with dogs (ABOSHEHADA \& ABU-HALAWEH, 2010; BARBER et al., 1997). Thus, identification of seropositive animals and seroprevalence data in dog populations is extremely important for control and prevention strategies.

In South America, there are variations in the prevalence of neosporosis in the canine population, for example: $20 \%$ in Uruguay (BARBER et al., 1997), 37.8\% in Argentina (BASSO et al., 2001) and $18 \%$ in Chile (PATITUCCI et al., 2001). In Brazil, the prevalence is between $8.4 \%$, which was found in the state of Paraiba state (AZEVEDO et al., 2005), and 15.6\% in the state of Rio Grande do Sul (CUNHA et al., 2008). These reports suggest that the average prevalence across all South American countries might be around $20 \%$.

The data obtained in the present study, with an assay using $20 \%$ as the prevalence for neosporosis in the canine population, produced sensitivity of $93.3 \%$ and specificity of $100 \%$, with positive and negative predictive values of $69.8 \%$ and $100 \%$, respectively. Moreover, using this ELISA test, we were able to discriminate between animals more specifically, among both sheep and dogs that had negative results in IFAT but were positive in our ELISA test, with confirmed positive results in the Western blot assay (Figure 1). This is important to note, since IFAT is still in use and is considered by many to be a gold-standard test for neosporosis.

In this study, we reported that the recombinant NcSRS2 protein expressed in $P$. pastoris was recognized in serum from two animal species with neosporosis using NcSRS2-ELISA. We observed that the specificity and sensitivity of this ELISA test is more satisfactory than IFAT, given that some serum samples were found to be positive through NcSRS2-ELISA and negative through IFAT. The Western blot analysis, which is a more specific approach, showed a reaction between these serum samples and the recombinant NcSRS2. Thus, the novel ELISA developed here may aid in studying the epidemiology of neosporosis and help in combat this infectious and economically significant disease. 


\section{Acknowledgements}

Funding for this study was provided by the Coordination Office for Improvement of University-level Personnel (Coordenação de Aperfeiçoamento de Pessoal de Nível Superior, CAPES, grant no. AUX-PE-PNPD-1513/2008) and the National Council for Scientific and Technological Development (Conselho Nacional de Desenvolvimento Científico e Tecnológico, CNPq). We also would like to thank Dr. Nilton Azevedo Cunha Filho and Dr. Felipe Papen for kindly providing the ovine and canine serum samples.

\section{References}

Abo-Shehada MN, Abu-Halaweh MM. Flock-level seroprevalence of, and risk factors for, Neospora caninum among sheep and goats in northern Jordan. Prev Vet Med 2010; 93(1): 25-32. http://dx.doi.org/10.1016/j. prevetmed.2009.08.004. PMid:19923025

Ahn HJ, Kim S, Kim DY, Nam HW. ELISA detection of IgG antibody against a recombinant major surface antigen (Nc-p43) fragment of Neospora caninum in bovine sera. Korean J Parasitol 2003; 41(3): 175-177. http:// dx.doi.org/10.3347/kjp.2003.41.3.175. PMid:12972732

Azevedo SS, Batista CS, Vasconcellos SA, Aguiar DM, Ragozo AM, Rodrigues AA, et al. Seroepidemiology of Toxoplasma gondii and Neospora caninum in dogs from the state of Paraíba, Northeast region of Brazil. Res Vet Sci 2005; 79(1): 51-56. http://dx.doi.org/10.1016/j.rvsc.2004.10.001. PMid:15894024

Barber JS, Gasser RB, Ellis J, Reichel MP, McMillan D, Trees AJ. Prevalence of antibodies to Neospora caninum in different canid populations. $J$ Parasitol 1997; 83(6): 1056-1058. http://dx.doi.org/10.2307/3284361. PMid:9406778

Basso W, Venturini L, Venturini MC, Moore P, Rambeau M, Unzaga JM, et al. Prevalence of Neospora caninum infection in dogs from beef-cattle farms, dairy farms, and from urban areas of Argentina. J Parasitol 2001; 87(4): 906-907. http://dx.doi.org/10.1645/0022-3395(2001)087[0906:PO NCII]2.0.CO;2. PMid:11534656

Borsuk S, Andreotti R, Leite FP, Pinto LS, Simionatto S, Hartleben CP, et al. Development of an indirect ELISA-NcSRS2 for detection of Neospora caninum antibodies in cattle. Vet Parasitol 2011; 177(1-2): 33-38. PMid:21168278.

Cereghino GP, Cereghino JL, Ilgen C, Cregg JM. Production of recombinant proteins in fermenter cultures of the yeast Pichia pastoris. Curr Opin Biotechnol 2002; 13(4): 329-332. http://dx.doi.org/10.1016/ S0958-1669(02)00330-0. PMid:12323354

Cunha NA Fo, Lucas AS, Pappen FG, Ragozo AM, Gennari SM, Junior TL, et al. [Risk factors and prevalence of antibodies anti-Neospora caninum in urban and rural dogs from Rio Grande do Sul, Brazil]. Rev Bras Parasitol Vet 2008; 17(Suppl 1): 301-306. PMid:20059865.

Dubey JP, Acland HM, Hamir AN. Neospora caninum (Apicomplexa) in a stillborn goat. J Parasitol 1992; 78(3): 532-534. http://dx.doi. org/10.2307/3283661. PMid:1597802

Dubey JP, Carpenter JL, Speer CA, Topper MJ, Uggla A. Newly recognized fatal protozoan disease of dogs. J Am Vet Med Assoc 1988; 192(9): 12691285. PMid:3391851.
Dubey JP, Lindsay DS, Adams DS, Gay JM, Baszler TV, Blagburn BL, et al. Serologic responses of cattle and other animals infected with Neospora caninum. Am J Vet Res 1996; 57(3): 329-336. PMid:8669764.

Dubey JP, Lindsay DS. Neospora caninum induced abortion in sheep. J Vet Diagn Invest 1990; 2(3): 230-233. http://dx.doi. org/10.1177/104063879000200316. PMid:2094452

Dubey JP, Ross AD, Fritz D. Clinical Toxoplasma gondii, Hammondia heydorni, and Sarcocystis spp. infections in dogs. Parassitologia 2003; 45(3-4): 141-146. PMid:15267102.

Dubey JP, Schares G, Ortega-Mora LM. Epidemiology and control of neosporosis and Neospora caninum. Clin Microbiol Rev 2007; 20(2): 323-367. http://dx.doi.org/10.1128/CMR.00031-06. PMid:17428888

Dubey JP, Schares G. Diagnosis of bovine neosporosis. Vet Parasitol 2006; 140(1-2): 1-34. http://dx.doi.org/10.1016/j.vetpar.2006.03.035. PMid:16730126

Fuchs N, Sonda S, Gottstein B, Hemphill A. Differential expression of cell surface- and dense granule-associated Neospora caninum proteins in tachyzoites and bradyzoites. J Parasitol 1998; 84(4): 753-758. http:// dx.doi.org/10.2307/3284583. PMid:9714206

Gaturaga I, Chahan B, Xuan X, Huang X, Liao M, Fukumoto S, et al. Detection of antibodies to Neospora caninum in cattle by enzyme-linked immunosorbent assay with truncated NcSRS2 expressed in Escherichia coli. J Parasitol 2005; 91(1): 191-192. http://dx.doi.org/10.1645/GE267R1. PMid:15856900

Ghalmi F, China B, Kaidi R, Losson B. Evaluation of a SRS2 sandwich commercial enzyme-linked immunosorbent assay for the detection of antiNeospora caninum antibodies in bovine and canine sera. J Vet Diagn Invest 2009; 21(1): 108-111. http://dx.doi.org/10.1177/104063870902100116. PMid:19139509

Gondim LF, Sartor IF, Hasegawa M, Yamane I. Seroprevalence of Neospora caninum in dairy cattle in Bahia, Brazil. Vet Parasitol 1999; 86(1): 71-75. http://dx.doi.org/10.1016/S0304-4017(99)00129-6. PMid:10489205

Hemphill A, Fuchs N, Sonda S, Hehl A. The antigenic composition of Neospora caninum. Int J Parasitol 1999; 29(8): 1175-1188. http://dx.doi. org/10.1016/S0020-7519(99)00085-5. PMid:10576569

Howe DK, Crawford AC, Lindsay D, Sibley LD. The p29 and p35 immunodominant antigens of Neospora caninum tachyzoites are homologous to the family of surface antigens of Toxoplasma gondii. Infect Immun 1998; 66(11): 5322-5328. PMid:9784539.

Liu J, Yu J, Wang M, Liu Q, Zhang W, Deng C, et al. Serodiagnosis of Neospora caninum infection in cattle using a recombinant tNcSRS2 protein-based ELISA. Vet Parasitol 2007; 143(3-4): 358-363. http:// dx.doi.org/10.1016/j.vetpar.2006.08.034. PMid:16989950

Nishikawa Y, Kousaka Y, Tragoolpua K, Xuan X, Makala L, Fujisaki $\mathrm{K}$, et al. Characterization of Neospora caninum surface protein NcSRS2 based on baculovirus expression system and its application for serodiagnosis of Neospora infection. J Clin Microbiol2001; 39(11):3987-3991. http:// dx.doi.org/10.1128/JCM.39.11.3987-3991.2001. PMid:11682519

Nishikawa Y, Claveria FG, Fujisaki K, Nagasawa H. Studies on serological cross-reaction of Neospora caninum with Toxoplasma gondii and Hammondia heydorni.JVet Med Sci 2002; 64(2): 161-164. http://dx.doi.org/10.1292/ jvms.64.161. PMid:11913555

Paré J, Hietala SK, Thurmond MC. Interpretation of an indirect fluorescent antibody test for diagnosis of Neospora sp. infection in cattle. J Vet Diagn Invest 1995; 7(2): 273-275. http://dx.doi.org/10.1177/104063879500700222. PMid:7619917 
Patitucci AN, Pérez MJ, Rozas MA, Israel KF. Neosporosis canine: detection of sera antibodies in rural and urban canine population of Chile. Arch Med Vet 2001; 33(2): 227-232. http://dx.doi.org/10.4067/ S0301-732X2001000200011.

Pinheiro AF, Borsuk S, Berne ME, Pinto LS, Andreotti R, Roos T, et al. Expression of Neospora caninum NcSRS2 surface protein in Pichia pastoris and its application for serodiagnosis of Neospora infection. Pathog Glob Health 2013; 107(3): 116-121. http://dx.doi.org/10.1179/204777321 3Y.0000000082. PMid:23683365

Romanelli PR, Freire RL, Vidotto O, Marana ER, Ogawa L, De Paula VS, et al. Prevalence of Neospora caninum and Toxoplasma gondii in sheep and dogs from Guarapuava farms, Paraná State, Brazil. Res Vet Sci 2007; 82(2): 202-207. http://dx.doi.org/10.1016/j.rvsc.2006.04.001. PMid:17266999

Sá GL, Pacheco DB, Monte LG, Sinnott FA, Xavier MA, Rizzi C, et al. Diagnostic potential of anti-rNcp-43 polyclonal antibodies for the detection of Neospora caninum. Curr Microbiol 2014; 68(4): 472-476. http://dx.doi.org/10.1007/s00284-013-0499-y. PMid:24310934
Soares HS, Ahid SM, Bezerra AC, Pena HF, Dias RA, Gennari SM. Prevalence of anti-Toxoplasma gondii and anti-Neospora caninum antibodies in sheep from Mossoró, Rio Grande do Norte, Brazil. Vet Parasitol 2009; 160(3-4): 211-214. http://dx.doi.org/10.1016/j.vetpar.2008.10.102. PMid:19091473

Ueno TE, Gonçalves VS, Heinemann MB, Dilli TL, Akimoto BM, de Souza SL, et al. Prevalence of Toxoplasma gondii and Neospora caninum infections in sheep from Federal District, central region of Brazil. Trop Anim Health Prod 2009; 41(4): 547-552. http://dx.doi.org/10.1007/ s11250-008-9220-8. PMid:18726165

Wouda W, Dijkstra T, Kramer AM, Bartels CJ. [The role of the dog in the epidemiology of neosporosis in cattle]. Tijdschr Diergeneeskd 2000, 125(20): 614-618. PMid:11060928.

Wouda W, Dijkstra T, Kramer AM, van Maanen C, Brinkhof JM. Seroepidemiological evidence for a relationship between Neospora caninum infections in dogs and cattle. Int J Parasitol 1999; 29(10): 1677-1682. http://dx.doi.org/10.1016/S0020-7519(99)00105-8. PMid:10608454 